\title{
EVALUATION ON SOCIAL CAPITAL OF SUSTAINABLE AGROFORESTRY SYSTEM: A CASE FROM ARGOSARI VILLAGE, MALANG
}

\author{
(Evaluasi Modal Sosial pada Sistem Agroforestri: Studi Kasus Desa Argosari, Malang)
}

\author{
Rita Parmawati ${ }^{1}$, Soemarno ${ }^{1,2}$, \& Agung Sih Kurnianto ${ }^{3}$ \\ ${ }^{1}$ Program of Natural Resources Management, Postgraduate, Brawijaya University, MT Haryono street, no. 169, \\ Malang, 65145, Indonesia; e-mail: ritaparmawati1990@gmail.com \\ ${ }^{2}$ Faculty of Agriculture, Brawijaya University, Veteran street, Malang, 65145, Indonesia; e-mail: smno@ub.ac.id \\ ${ }^{3}$ Ecology and Animal Diversity Laboratory, Biology Departement, Faculty of Sciences, Veteran street, Malang, \\ 65145, Indonesia; e-mail: agung.sih.kurnianto@gmail.comd
}

Diterima 30 Juni 2019, direvisi 4 September 2019, disetujui 21 Oktober 2019.

\begin{abstract}
Agroforestry activities are carried out in order to obtain community welfare, both in and around forests and at the same time also to maintain primary forest. Agroforestry can provide long-term benefits, such as increased crop productivity, more sustainable land use, as well as soil and environmental conservation. The success of forest management through agroforestry is determined by the level of community participation in forest management and the quality of human resources. The aim of the research is to identify and analyze several factors that strengthen social capital of agroforestry system in Argosari village and its sustainability. Using quantitative approach with Multi Dimensional Scaling (MDS)-Rap-agroforestry, all research variable (trust, ecology, social, and agroforestry) perceived as neutral by respondents. The Rap-agroforestry found that all dimensions studied are quite accurate and can be justified, where stress value ranges between 0.15-0.21 and coefficient of determination value is 0.910.97 . The sustainability index is as follows: ecology (54.68), economy (36.46), and social (45.40). The difference between the sustainability index and Monte Carlo are so small : ecology (0.32), economy (0.86), and social (0.31), so that the sustainability index can be used to conduct a sustainability assesment of the agroforestry system in Argosari village. This should be considered for future policy formulation.
\end{abstract}

Keywords: Agroforestry; sustainability; Multi Dimensional Scaling.

\begin{abstract}
ABSTRAK
Kegiatan agroforestri dilakukan untuk memperoleh kesejahteraan masyarakat, di dalam dan di sekitar hutan. Agroforestri dapat memberikan manfaat jangka panjang seperti peningkatan produktivitas tanaman, penggunaan lahan yang lebih berkelanjutan, konservasi tanah dan lingkungan. Keberhasilan pengelolaan hutan melalui agroforestri antara lain ditentukan oleh tingkat partisipasi masyarakat dalam pengelolaan hutan dan kualitas sumberdaya manusia. Tingginya partisipasi masyarakat akan berdampak pada meningkatnya kelestarian hutan beserta sumberdaya alam di dalamnya. Penelitian ini bertujuan untuk mengidentifikasi dan menganalisis faktor-faktor yang memperkuat modal sosial dalam pelaksanaan sistem agroforestri di Desa Argosari dan keberlanjutannya. Penelitian ini menggunakan pendekatan kuantitatif dengan Multi Dimensional Scaling (MDS)-Rap-agroforestry. Semua instrumen penelitian (kepercayaan, ekologi, sosial, dan agroforestri), pendapat, dan pernyataan responden pada umumnya pada tingkat sedang atau netral (tidak memiliki pendapat yang condong). Hasil Rap-agroforestry menunjukkan bahwa semua dimensi yang diteliti cukup akurat dan dapat dipertanggungjawabkan, di mana nilai stres berkisar antara 0,15-0,21 dan nilai koefisien determinasi adalah 0,91-0,97. Indeks keberlanjutan adalah: ekologi $(54,68)$, ekonomi $(36,46)$, dan sosial $(45,40)$. Perbedaan indeks keberlanjutan dan Monte Carlo adalah sangat kecil, yaitu: ekologi (0,32), ekonomi (0,86), dan sosial (0,31) sehingga indeks keberlanjutan dapat digunakan untuk melakukan penilaian keberlanjutan dari sistem agroforestri di Desa Argosari. Hal ini sangat penting untuk perumusan kebijakan di masa depan.
\end{abstract}

Kata kunci: Agroforestry; keberlanjutan; Modal sosial. 


\section{INTRODUCTION}

Agroforestry is a land use system that combines trees with agricultural crops to increase profits, both economically and environmentally. Agroforestry farming systems have played a role in the socialeconomic life of the Indonesian people for a long time. Traditionally, this system has been implemented to obtain sustainable benefits and to maintain forest sustainability (de Foresta, Kusworo, Michon, \& Djatmiko, 2000). Agroforestry activities are carried out to obtain community welfare, both in and around forests while maintaining primary forest. Agroforestry can provide long-term benefits, such as increased crop productivity, more sustainable land use and environmental conservation (Mayrowani \& Ashari, 2011).

However, the growth of agroforestry systems in Indonesia is very slow. This is because of community participation is getting lower and weak social institutions. The success of forest management through agroforestry is determined by the level of community participation in forest management and the quality of human resources (de Foresta et al., 2000). Agroforestry as a form of community development and land rehabilitation efforts is absolutely necessary to build an advanced and self-sustaining community (Ministry of Forestry, 2006).

Social capital is a heritage of ancestors in the values of life that blend in the form of religion, culture, and customs (Suhartini, 2009). This capital is a mix value between individuals that enable them to create new values and is formed from a small level to a wider population (Putnam, 2001; Field, 2005). Social capital cannot be separated from various challenges such as population growth, modern technology and culture, economic stability, poverty, and social inequality. Nababan (2003) argues that research has shown that indigenous communities in Indonesia through social capital have traditionally manage natural biodiversity and use it as a source of income.

Argosari village, Jabung sub-district, Malang regency is one of the buffer villages of Bromo Tengger Semeru National Park (TNBTS). The agroforestry system in Argosari village has been developed together with local farms. This study places social capital issue in agroforestry preservation as the main subject. Sustainable agroforest is more focused on community based management. The purpose of this research is to analyze factors that strengthen social capital of agroforestry system in Argosari village and analyze its sustainability.

\section{METHODS}

\section{A. Data Collection}

Preliminary study was held by determining the location purposively. Argosari village selection, in Jabung subdistrict, Malang regency, was chosen. This village selection has some considerations: 1) villages with poverty-prone status, 2) receive national Kalpataru award, 3) active farmer group (Bina Usaha Maju II) that concerning on forest sustainability, 4) independently capable of establishing renewable energy installation (biogas).

This research used quantitative approach with multi-dimensional scaling (MDS) with Rapfish (Rapid appraisal for fisheries) software. Rapfish software was developed initially to analyze the sustainability of fisheries by Columbia University in 1999. However, in its development, it was used also with a system of adaptation to sustainability issues that were not limited to the fisheries sector only (Fauzi \& Anna, 2002; Fauzi, 2004; Fauzi \& Anna, 2005; Kavanagh \& Pitcher, 2004). We used modified Rapfish according to the needs of this study (RAPagroforestry). In this study, we use MDS that is aimed at the sustainability of social capital in agroforestry based on 3 dimensions: ecological, social, and economic. 
Participatory Rapid Appraisal (PRA) is used with 30 respondents to approach and reveal the problems holistically (Preece, 2006). Snowball technique is used to determine the respondent who has suitable background to know the real condition. Then, in-depth interviews were conducted on farmer groups that linear to variables of data. Primary data consist of questionnaires interviews result on all members of the farmer group, in the form of farmers' perceptions regarding norms, trust, social institutions, and forest preservation (Appendix). Secondary data include of village documents as well as farmer groups. Existing farmer groups were formed in 1998. This group emerged after the environmental disaster that struck the Argosari village due to deforestation in previous years. Existing farmer groups were formed in 1998. This group emerged after the environmental disaster that struck the village of Argosari due to forest looting in previous years. Today, this group is at the core of strength in preserving forests around Argosari and strengthening the social and economic structure of society. Direct observation and documentation are performed to illustrate the condition of the village and support the results of the analysis.

Likert scale is used to declare the category, rank, and distance of construction as measured. We used 5 alternative answers that describe respondent's perception (Table $1)$.

\section{B. Analysis}

\section{Validity-Reliability Test}

Validity test is done by comparing the
Pearson moment product moment correlation index with a significance value of 5\% and its critical value. If the correlation value is more than 0.3 , then it is declared valid, and otherwise not (Arikunto, 2006). Cronbanchalpha is used to test reliability. Instruments can be said as reliable if they have reliability comfort of 0.6 or more (Arikunto, 2006).

\section{Descriptive-Quantitative}

Confirmatory factor analysis is used to confirm the indicator element that defines the variables (Augusty, 2006). These variables are: trust (X1), ecology (X2), social (X3), and agroforestry (Y). All of these cannot be observed and measured directly based on interviews and questionnaires. Then, the variables are grouped by their correlation (Appendix).

\section{Path Analysis}

Path analysis is held by comparing the theoretical and empirical models. The compatibility of them will result in the acceptance of the theoretical model as an alternative policy that can revise the empirical model. Structural Equation Modeling (SEM) is used to describe the relation between dimensions.

\section{Rapid Appraisal Analysis for Agroforestry (Rap-agroforestry) and Multi Dimensional Scaling (MDS) Method}

Rap-agroforestry is used together with MDS method. Both are used in order to understand the level of sustainability of agroforestry systems that implemented in Argosari village. The technique is based on 3 dimensions: economic, social, and

Table 1 The Likert scale of main variable data Tabel 1 Skala Likert dari variabel utama

\begin{tabular}{ccl}
\hline Answer choices (Pilihan Jawaban) & Score (Skor) & \multicolumn{1}{c}{ Remark (Keterangan) } \\
\hline B & 4 & Agree (Setuju) \\
C & 3 & Neutral (Netral) \\
D & 2 & Disagree (Tidak setuju) \\
E & 1 & Strongly disagree (Sangat tidak setuju)
\end{tabular}

Source (Sumber): Singarimbun \& Effendi (1995). 
ecology. All three dimensions will be evaluated to reflect sustainability, and can detect the weakness of agroforestry system progress in Argosari village. Each dimension has attributes/indicators related to the sustainability of the forest. In the MDS analysis, the scored data show the status of the resource (0-100; Table 2).

\section{RESULT AND DISCUSSION}

\section{A. Validity and Reliability Test of Questionnaire}

We measure the variables of each respondent's answer. The variables are measured by mean of respondent's answers category. Respondents are categorized in 5 levels: very low (mean between 1.00-1.80), low (1.81-2.60), fair (2.61-3.40), high (3.41-
4.20), and very high (4.21-5.00).These categories are used to interpret the real picture of the condition of sustainability in each study on the below variable.

\section{Trust Variable (X1)}

All three indicators of trust variable are perceived as neutral by respondents (Table 3). Similarly, the mean confidence variable (X1). This shows that community have a positive perception about conservation.

The first indicator is the prohibition of cutting down productive trees (X1.1). The most of respondents answered neutral (33$49 \%$ ) and some residents answered disagree (17-28\%). None of respondents strongly disagree. The mean of answers is 3.22 , or in the fair category. The high number of respondents who agree indicates that the

Table 2 Sustainability status of agroforestry

Tabel 2 Status keberlanjutan dari agroforestri

\begin{tabular}{cl}
\hline $\begin{array}{c}\text { MDS analysis result index } \\
(\text { Nilai indeks } M D S)\end{array}$ & \multicolumn{1}{c}{$\begin{array}{c}\text { Category } \\
\text { (Kategori) }\end{array}$} \\
\hline $0.00-25.00$ & Bad/unsustainable (Buruk/tidak berkelanjutan) \\
$25.00-50.00$ & Less/less sustainable (Kurang/kurang berkelanjutan) \\
$50.00-75.00$ & Neutral/fairly sustainable (Netral/cukup berkelanjutan) \\
$75.00-100.00$ & Good/very sustainable (Baik/sangat berkelanjutan) \\
\hline
\end{tabular}

Source (Sumber): Thamrin (2008), Susilo (2003).

Table 3 Distribution of respondents' answer on trust variables (X1)

Tabel 3 Distribusi jawaban responden dari variabel kepercayaan (X1)

\begin{tabular}{|c|c|c|c|c|c|c|c|c|}
\hline \multirow{2}{*}{$\begin{array}{l}\text { Indicator } \\
\text { (Indikator) }\end{array}$} & \multirow[b]{2}{*}{ Item } & \multicolumn{5}{|c|}{ Percentage of answer (Persentase jawaban) } & \multicolumn{2}{|c|}{ Mean (Rata-rata) } \\
\hline & & $\mathrm{SD}$ & $\mathrm{D}$ & $\mathrm{N}$ & A & SA & Item & $\begin{array}{l}\text { Indicator } \\
\text { (Indikator) }\end{array}$ \\
\hline \multirow[t]{3}{*}{$\mathrm{X} 1.1$} & $\mathrm{X} 1.1 .1$ & 0.00 & 28.46 & 40.00 & 19.23 & 12.31 & 3.15 & 3.22 \\
\hline & $\mathrm{X} 1.1 .2$ & 0.00 & 26.92 & 33.08 & 30.77 & 9.23 & 3.22 & \\
\hline & $\mathrm{X} 1.1 .3$ & 0.00 & 17.69 & 49.23 & 20.00 & 13.08 & 3.28 & \\
\hline \multirow[t]{3}{*}{$\mathrm{X} 1.2$} & $\mathrm{X} 1.2 .1$ & 0.00 & 23.08 & 34.62 & 30.00 & 12.31 & 3.32 & 3.32 \\
\hline & $\mathrm{X} 1.2 .2$ & 0.00 & 20.77 & 36.15 & 29.23 & 13.85 & 3.36 & \\
\hline & X1.2.3 & 0.00 & 25.38 & 36.92 & 23.08 & 14.62 & 3.27 & \\
\hline \multirow[t]{3}{*}{ X1.3 } & X1.3.1 & 0.00 & 23.08 & 36.92 & 30.00 & 10.00 & 3.27 & 3.25 \\
\hline & X1.3.2 & 0.00 & 20.77 & 34.62 & 31.54 & 13.08 & 3.37 & \\
\hline & X1.3.3 & 0.00 & 30.77 & 33.85 & 27.69 & 7.69 & 3.12 & \\
\hline $\mathrm{X} 1$ & & & & & & & & 3.26 \\
\hline
\end{tabular}

Source (Sumber): Data analysis, 2019

Remarks (Keterangan): SD/strongly disagree (STS/sangat tidak setuju); D/disagree (TS/tidak setuju); N/neutral (N/Netral); A/agree (S/setuju); SA/strongly agree (SS/sangat setuju). 
prohibition of cutting down productive trees (X1.1) has been applied well enough by the respondents (community) in terms of growing public aware in traditional conservation. Respondents who neutral showed their ignorance of the function of productive trees directly on their lives. The number of respondents who answered did not agree indicates their desire to use trees productively as logging. This is based on their knowledge that the forest has been owned and managed by the community from traditional ancestors, including logging, and rotation planting (Parotta et al., 2009).

The second indicator is the maintenance of environmental balance (X1.2), the majority of respondents answered neutral (34-36\%), and none of respondents strongly disagree, although some residents answered disagree $(20-25 \%)$. The mean indicator of maintenance of environmental balance (X1.2) is 3.32 , or in the medium category. This indicates that the maintenance of environmental balance (X1.2) has been done fairly well by the respondent (community) in conservation.

The third indicator is the success of planting (X1.3), the majority of respondents answered neutrally (33-36\%), and none respondents strongly disagree, although some residents answered disagree (20-30\%). From the average of respondent's answer, mean indicator of success of planting (X1.3) equal to 3.25 in medium category. This indicates that success of planting (X1.3) has been run quite well by the respondents (community) in conservation terms. Most respondents who agreed showed that they wanted to preserve the environment by planting. Respondents with neutral answers showed their ignorance of the direct benefits of environmental sustainability in their lives. Respondents who answered did not agree to show the attitude of those who want to manage forest land with their economic version, such as agriculture or fodder fields (Parotta, Fui, Jinlong, Ramakrishnan, \& Yeo-Chang, 2009).

\section{Ecology Variable (X2)}

The four indicators of ecology variable concluded as neutral by respondents (Table 4). This shows that the community is upholding a good norm about the forest in their environment.

Table 4 Distribution of respondents' answer on trust variables (X2)

Tabel 4 Distribusi jawaban responden pada variabel ekologi (X2)

\begin{tabular}{|c|c|c|c|c|c|c|c|c|}
\hline \multirow{2}{*}{$\begin{array}{l}\text { Indicator } \\
\text { (Indikator) }\end{array}$} & \multirow[b]{2}{*}{ Item } & \multicolumn{5}{|c|}{ Percentage of answer (Persentase jawaban) } & \multicolumn{2}{|c|}{ Mean (Rata-rata) } \\
\hline & & SD & $\mathrm{D}$ & $\mathrm{N}$ & A & SA & Item & $\begin{array}{l}\text { Indicator } \\
\text { (Indikator) }\end{array}$ \\
\hline \multirow[t]{3}{*}{$\mathrm{X} 2.1$} & $\mathrm{X} 2.1 .1$ & 0.00 & 29.23 & 33.08 & 27.69 & 10.00 & 3.18 & 3.26 \\
\hline & $\mathrm{X} 2.1 .2$ & 0.00 & 24.62 & 33.85 & 26.15 & 15.38 & 3.32 & \\
\hline & $\mathrm{X} 2.1 .3$ & 0.00 & 23.85 & 36.15 & 28.46 & 11.54 & 3.28 & \\
\hline \multirow[t]{3}{*}{$\mathrm{X} 2.2$} & $\mathrm{X} 2.2 .1$ & 0.00 & 30.00 & 38.46 & 21.54 & 10.00 & 3.12 & 3.19 \\
\hline & $\mathrm{X} 2.2 .2$ & 0.00 & 28.46 & 40.00 & 22.31 & 9.23 & 3.12 & \\
\hline & $\mathrm{X} 2.2 .3$ & 0.00 & 19.23 & 41.54 & 24.62 & 14.62 & 3.35 & \\
\hline \multirow[t]{3}{*}{$\mathrm{X} 2.3$} & $\mathrm{X} 2.3 .1$ & 0.00 & 20.77 & 43.85 & 26.15 & 9.23 & 3.24 & 3.21 \\
\hline & $\mathrm{X} 2.3 .2$ & 0.00 & 25.38 & 33.85 & 30.77 & 10.00 & 3.25 & \\
\hline & $\mathrm{X} 2.3 .3$ & 0.00 & 23.85 & 45.38 & 23.08 & 7.69 & 3.15 & \\
\hline \multirow[t]{3}{*}{ X2.4 } & $\mathrm{X} 2.4 .1$ & 0.00 & 21.54 & 42.31 & 30.00 & 6.15 & 3.21 & 3.20 \\
\hline & $\mathrm{X} 2.4 .2$ & 0.00 & 31.54 & 38.46 & 18.46 & 11.54 & 3.10 & \\
\hline & $\mathrm{X} 2.4 .3$ & 0.00 & 20.77 & 39.23 & 29.23 & 10.77 & 3.30 & \\
\hline $\mathrm{X} 2$ & & & & & & & & 3.22 \\
\hline
\end{tabular}

Source (Sumber): Data analysis, 2019

Remarks (Keterangan): SD/strongly disagree (STS/sangat tidak setuju); D/disagree (TS/tidak setuju); N/neutral (N/Netral); A/agree (S/setuju); SA/strongly agree (SS/sangat setuju). 
The first indicator of the ban on cutting trees (X2.1), the majority of respondents answered neutrally (33-36\%) and some residents answered disagree (23-29\%). From the average number of respondents' answers, the mean of the logging prohibition indicator (X2.1) is 3.26 or classified as medium category. These indicate that the ban on cutting trees has been done well enough by the respondents (the community) in terms of enforcing the norm to conservation. However, most of the following communities expressed their agreement to the ban on logging. The community wants a restriction of large scale logging that will damage the quality of the environment (Lim, Choi, Kim, Jeon, \& Lee, 2007).

The second indicator is planting crops around the forest (X2.2), the majority of respondents answered neutrally (38-41\%), and none of the respondents answered strongly disagree, although some residents answered disagree (19-30\%). From the average number of respondents' answers, the mean (mean) indicator is 3.19 or classified as medium category. This indicates that planting crops around the forest has been run well enough by the respondent (community) in terms of enforcing the norms to preserve the forest. The agricultural area around the protected forest becomes a buffer. This area is very important to be managed sustainably, which is the focus of the community's economic development so that it does not damage the forest (Lim et al., 2017). The third indicator is replanting for sustainability (X2.3), the majority of respondents answered neutrally (33-45\%) and none respondents strongly disagree. The mean of respondents' answers is 3.21 or classified as medium category. This indicates that the replanting for sustainability has been done well enough by the respondent (community), in terms of forest conservation.

The fourth indicator is the tradition event relating to nature (X2.4). The most of respondents answered neutrally (38-42\%), and none of the respondents answered strongly disagree. Some of residents answered disagree (20-31\%). The mean of answer is 3.20 or in the medium category. This indicates that tradition event relating to nature has been done fairly well by the respondents (the community) in terms of enforcing the norm to preserve the forest.

\section{Social Variable (X3)}

All three indicators (Deb, Arunachalam, $\&$ Das, 2009) of this variable are perceived by respondents as neutral (Table 5). This

Table 5 Distribution of respondents' answer on social institution variables (X3)

Table 5 Distribusi jawaban responden pada variabel sosial (X3)

\begin{tabular}{|c|c|c|c|c|c|c|c|c|}
\hline \multirow{2}{*}{$\begin{array}{l}\text { Indicator } \\
\text { (Indikator) }\end{array}$} & \multirow[b]{2}{*}{ Item } & \multicolumn{5}{|c|}{ Percentage of answer (Persentase jawaban) } & \multicolumn{2}{|c|}{ Mean (Rata-rata) } \\
\hline & & SD & $\mathrm{D}$ & $\mathrm{N}$ & A & SA & Item & $\begin{array}{l}\text { Indicator } \\
\text { (Indikator) }\end{array}$ \\
\hline \multirow[t]{3}{*}{$\mathrm{X} 3.1$} & $\mathrm{X} 3.1 .1$ & 0.00 & 23.08 & 37.69 & 26.15 & 13.08 & 3.29 & 3.25 \\
\hline & $\mathrm{X} 3.1 .2$ & 0.00 & 25.38 & 37.69 & 20.77 & 16.15 & 3.28 & \\
\hline & $\mathrm{X} 3.1 .3$ & 0.00 & 29.23 & 36.15 & 23.08 & 11.54 & 3.17 & \\
\hline \multirow[t]{3}{*}{$\mathrm{X} 3.2$} & $\mathrm{X} 3.2 .1$ & 0.00 & 30.00 & 33.85 & 26.92 & 9.23 & 3.15 & 3.23 \\
\hline & $\mathrm{X} 3.2 .2$ & 0.00 & 18.46 & 47.69 & 23.85 & 10.00 & 3.25 & \\
\hline & X3.2.3 & 0.00 & 27.69 & 33.85 & 22.31 & 16.15 & 3.27 & \\
\hline \multirow[t]{3}{*}{ X3.3 } & X3.3.1 & 0.00 & 23.85 & 33.08 & 32.31 & 10.77 & 3.30 & 3.25 \\
\hline & $\mathrm{X} 3.3 .2$ & 0.00 & 22.31 & 45.38 & 24.62 & 7.69 & 3.18 & \\
\hline & X3.3.3 & 0.00 & 23.08 & 39.23 & 25.38 & 12.31 & 3.27 & \\
\hline X3 & & & & & & & & 3.24 \\
\hline
\end{tabular}

Source (Sumber): Data analysis, 2019

Remarks (Keterangan): SD/strongly disagree (STS/sangat tidak setuju); D/disagree (TS/tidak setuju); N/neutral (N/Netral); A/agree (S/setuju); SA/strongly agree (SS/sangat setuju). 
indicates that the community is upholding the social order (X3) that is good enough about the forest in their environment.

The first indicator is institutional goals (X3.1). The majority of respondents answered neutrally (36-37\%) and some residents answered disagree (18-30\%). The mean indicator of institutional goals is 3.25. This indicates that the institutional objectives (X3.1) have been done well enough by the respondents (the community) in terms of maintaining social institutions (such as non government organization/NGO or farmer group) for forest sustainability. This figures that the conservative behavior of the Argosari community was initiated and supported by the village government, and achieved its objectives.

The second indicator is the institutional structure (X3.2). The majority of respondents answered neutrally (33-47\%) and some citizens responded disagree (18-30\%). The mean indicator of institutional structure is 3.23 (medium category). This indicates that the institutional structure (X3.2) has been implemented well enough by the community in terms of maintaining social institutions for forest sustainability. This shows that the conservative behavior of the community was initiated and supported by the existing social structure such as NGO or farmer group.

The third indicator is the effectiveness of the institution (X3.3). The majority of respondents answered neutrally (33-45\%) and some residents answered disagree $(22-23 \%)$. The mean indicator is 3.25 , or medium category. This indicates that the effectiveness of the institutional (X3.3) has been run quite well by the respondent (community) in terms of maintaining social institutions for the sustainability of the forest. This illustrates that the conservative behavior of village communities is initiated and supported by village institutions quite effectively.

\section{Agroforestry Variable (Y)}

All three indicators of agroforestry variable are perceived as neutral by respondents (Table 6). Similarly, the mean (mean) variables agroforestry (forest preservation) (Y). This shows that the implementation (yield) of agroforestry (forest conservation) (Y) has been running fairly well.

The first indicator of ecological sustainability (Y1). The majority of respondents answered neutral (35-39\%)

Table 6 Answers distribution of respondents' on agroforestry variables (forest conservation) (Y)

Table 6 Distribusi jawaban responden pada variabel Agroforestri (Y)

\begin{tabular}{|c|c|c|c|c|c|c|c|c|}
\hline \multirow{2}{*}{$\begin{array}{l}\text { Indicator } \\
\text { (Indikator) }\end{array}$} & \multirow[b]{2}{*}{ Item } & \multicolumn{5}{|c|}{ Percentage of answer (Persentase jawaban) } & \multicolumn{2}{|c|}{ Mean (Rata-rata) } \\
\hline & & $\mathrm{SD}$ & $\mathrm{D}$ & $\mathrm{N}$ & A & SA & Item & $\begin{array}{l}\text { Indicator } \\
\text { (Indikator) }\end{array}$ \\
\hline \multirow[t]{3}{*}{ Y1 } & Y1.1 & 0.00 & 21.54 & 39.23 & 23.85 & 15.38 & 3.33 & 3.35 \\
\hline & Y1.2 & 0.00 & 23.08 & 35.38 & 25.38 & 16.15 & 3.35 & \\
\hline & Y1.3 & 0.00 & 20.00 & 38.46 & 26.15 & 15.38 & 3.37 & \\
\hline \multirow[t]{3}{*}{$\mathrm{Y} 2$} & $\mathrm{Y} 2.1$ & 0.00 & 20.00 & 40.00 & 26.15 & 13.85 & 3.34 & 3.30 \\
\hline & $\mathrm{Y} 2.2$ & 0.00 & 24.62 & 39.23 & 25.38 & 10.77 & 3.22 & \\
\hline & Y2.3 & 0.00 & 24.62 & 30.77 & 30.00 & 14.62 & 3.35 & \\
\hline \multirow[t]{3}{*}{ Y3 } & Y3.1 & 0.00 & 26.92 & 40.77 & 20.77 & 11.54 & 3.17 & 3.19 \\
\hline & Y3.2 & 0.00 & 22.31 & 37.69 & 28.46 & 11.54 & 3.29 & \\
\hline & Y3.3 & 0.00 & 31.54 & 36.15 & 23.08 & 9.23 & 3.10 & \\
\hline $\mathrm{Y}$ & & & & & & & & 3.28 \\
\hline
\end{tabular}

Source (Sumber): Data analysis, 2019

Remarks (Keterangan): SD/strongly disagree (STS/sangat tidak setuju); D/disagree (TS/tidak setuju); N/neutral (N/Netral); A/agree (S/setuju); SA/strongly agree (SS/sangat setuju). 
and some residents responded disagree (20-23\%). From the average number of respondents' answers, the mean indicator of ecological sustainability (Y1) is 3.35 in the medium category. This indicates that respondents perceive being on the indication of ecological sustainability (Y1) on agroforestry (Y) variables. That is, ecological sustainability (Y1) has been done fairly well by the respondents (community) in terms of achieving agroforestry (forest conservation). This illustrates community support in conservation and ecological sustainability.

Thesecondindicatoris socialsustainability (Y2), the majority of respondents answered neutrally (30-40\%), and none respondents strongly disagree, although some citizens responded disagree (20-24\%). From the average number of respondents' answers, the mean indicator of social sustainability (Y2) is 3.30 in the medium category. This indicates that the respondent perceives being on the indication of social sustainability (Y2) on agroforestry ( $\mathrm{Y}$ ) variables. That is, social sustainability (Y2) has been done well enough by the respondents (community) in terms of achieving agroforestry (forest conservation). This illustrates community support in conservation and sustainability of social conditions.

The third indicator is economic sustainability (Y3), the majority of respondents answered neutrally (36-40\%), and none respondents strongly disagree, although some residents responded disagree
$(22-31 \%)$. From the average number of respondents' answers, the mean indicator of economic sustainability (Y3) is 3.19 in the medium category. This indicates that the respondent perceives the indication of economic sustainability (Y3) on agroforestry $(\mathrm{Y})$ variables. That is, economic sustainability (Y3) has been implemented well enough by the respondent (community) in terms of achieving agroforestry (forest conservation). This figures community support in conservation and sustainability of economic conditions, such as from coffee and clove plantations.

\section{B. Measurement Model in Agroforestry}

This model is measured from the loading factor value of each indicator to the latent variable. The loading factor value shows the weight of each indicator as a measure of each variable. An indicator with a large loading factor means that the indicator is the strongest (dominant) variable.

The first variable is the trust variable (X1) measured by three indicators: the prohibition of cutting down productive trees (X1.1), maintaining environmental balance (X1.2), and planting success (X1.3). Table 7 presented the measurement model results, where the indicator with $\mathrm{CR}>1.96$ or $\mathrm{P}<0.05$ and the fixed indicator expressed as a measure of belief variable (X1).

The second variable is norm variable (X2) measured by four indicators: prohibition of cutting trees (X2.1), planting of forest plants (X2.2), replanting for sustainability (X2.3),

Table 7 Results of measurement model on confidence variables (X1)

Tabel 7 Hasil model pengukuran pada variabel kepercayaan (XI)

\begin{tabular}{lccc}
\hline \multicolumn{1}{c}{ Indicator (Indikator) } & $\begin{array}{c}\text { Standard value } \\
\text { (Nilai standar) }\end{array}$ & CR & P \\
\hline $\begin{array}{l}\text { Prohibition to cut down productive trees (Larangan menebang pohon } \\
\text { produktif) (X1.1) }\end{array}$ & 0.662 & FIX & FIX \\
$\begin{array}{l}\text { Maintenance of environmental balance (Pemeliharaan keseimbangan } \\
\text { lingkungan) (X1.2) }\end{array}$ & 0.636 & 5.747 & 0.001 \\
Successful planting (Penanaman yang sukses) (X1.3) & 0.694 & 6.108 & 0.001 \\
\hline
\end{tabular}

Source (Sumber): Data analysis, 2019. 
Table 8 Results of measurement model on ecology variable (X2)

Table 8 Hasil model pengukuran pada variabel ecology (X2)

\begin{tabular}{|c|c|c|c|}
\hline Indicator (Indikator) & $\begin{array}{l}\text { Standard value } \\
\text { (Nilai standar) }\end{array}$ & $\mathrm{CR}$ & $\mathrm{P}$ \\
\hline Prohibition to cut down trees (Larangan menebang pohon) (X2.1) & 0.535 & 4.773 & 0.001 \\
\hline Planting around the forest (Menanam di sekitar hutan) (X2.2) & 0.689 & 5.638 & 0.001 \\
\hline $\begin{array}{l}\text { Replanting for sustainability (Penanaman kembali untuk } \\
\text { keberlanjutan) (X2.3) }\end{array}$ & 0.569 & 5.005 & 0.001 \\
\hline $\begin{array}{l}\text { Traditional events related to nature conservation (Peristiwa } \\
\text { tradisional terkait dengan pelestarian alam) (X2.4) }\end{array}$ & 0.665 & FIX & FIX \\
\hline
\end{tabular}

Source (Sumber): Data analysis, 2019.

Table 9 Results of measurement model on social institution variable (X3)

Tabel 9 Hasil pengukuran pada variabel institusi sosial (X3)

\begin{tabular}{lccc}
\hline \multicolumn{1}{c}{$\begin{array}{c}\text { Indicator } \\
\text { (Indikator) }\end{array}$} & $\begin{array}{c}\text { Standard value } \\
\text { (Nilai standar) }\end{array}$ & CR & P \\
\hline Institutional goals (Tujuan kelembagaan) (X3.1) & 0.597 & FIX & FIX \\
Institutional structure (Struktur kelembagaan) (X3.2) & 0.761 & 5.842 & 0.001 \\
The effectiveness of the institution (Efektivitas lembaga) (X3.3) & 0.630 & 5.299 & 0.001 \\
\hline
\end{tabular}

Source (Sumber): Data analysis, 2019.

Table 10 Results of measurement model on agroforestry variable (Y)

Tabel 10 Hasil pengukuran pada variabel agroforestri (Y)

\begin{tabular}{lccc}
\hline \multicolumn{1}{c}{$\begin{array}{c}\text { Indicator } \\
\text { (Indikator) }\end{array}$} & $\begin{array}{c}\text { Standard value } \\
\text { (Nilai standar) }\end{array}$ & CR & P \\
\hline Ecological sustainability (Keberlanjutan ekologis) (Y1) & 0.639 & FIX & FIX \\
Social sustainability (Keberlanjutan sosial) (Y2) & 0.761 & 5.842 & 0.001 \\
Social sustainability (Keberlanjutan sosial) (Y2) & 0.630 & 5.299 & 0.001 \\
\hline
\end{tabular}

Source (Sumber): Data analysis, 2019.

as well as customary events related to nature X2.4). Table 8 presented measurement model results, where the indicator with $\mathrm{CR}>1.96$ or $\mathrm{P}<0.05$ and fixed indicators, otherwise indicated as norm variable gauge (X2).

The third variable is social institution variable (X3) measured by three indicators: institutional goals (X3.1), institutional structure (X3.2), and institutional effectiveness (X3.3). Table 9 presented measurement model measurement results, where indicators with $\mathrm{CR}>1.96$ or $\mathrm{P}<0.05$ and fixed indicators expressed as a measure of social variables (X3).

The fourth variable is agroforestry variable $(\mathrm{Y})$ measured by three indicators: ecological sustainability (Y.1), social sustainability (Y.2), and economic sustainability (Y.3). Table 10 presented measurement model results, where the indicator with $\mathrm{CR}>1.96$ or $\mathrm{P}<0.05$ and fixed indicators, otherwise indicated as a measure of agroforestry variables (Y). The flowchart of these variables can be explained through the Path of SEM analysis results (Figure 1).

\section{Sustainability Analysis of Agroforestry System Conservation}

The result of analysis using Rapagroforestry software shows that all dimensions studied are ecological dimension, economic dimension, and social dimension is quite accurate and can be accounted for, 


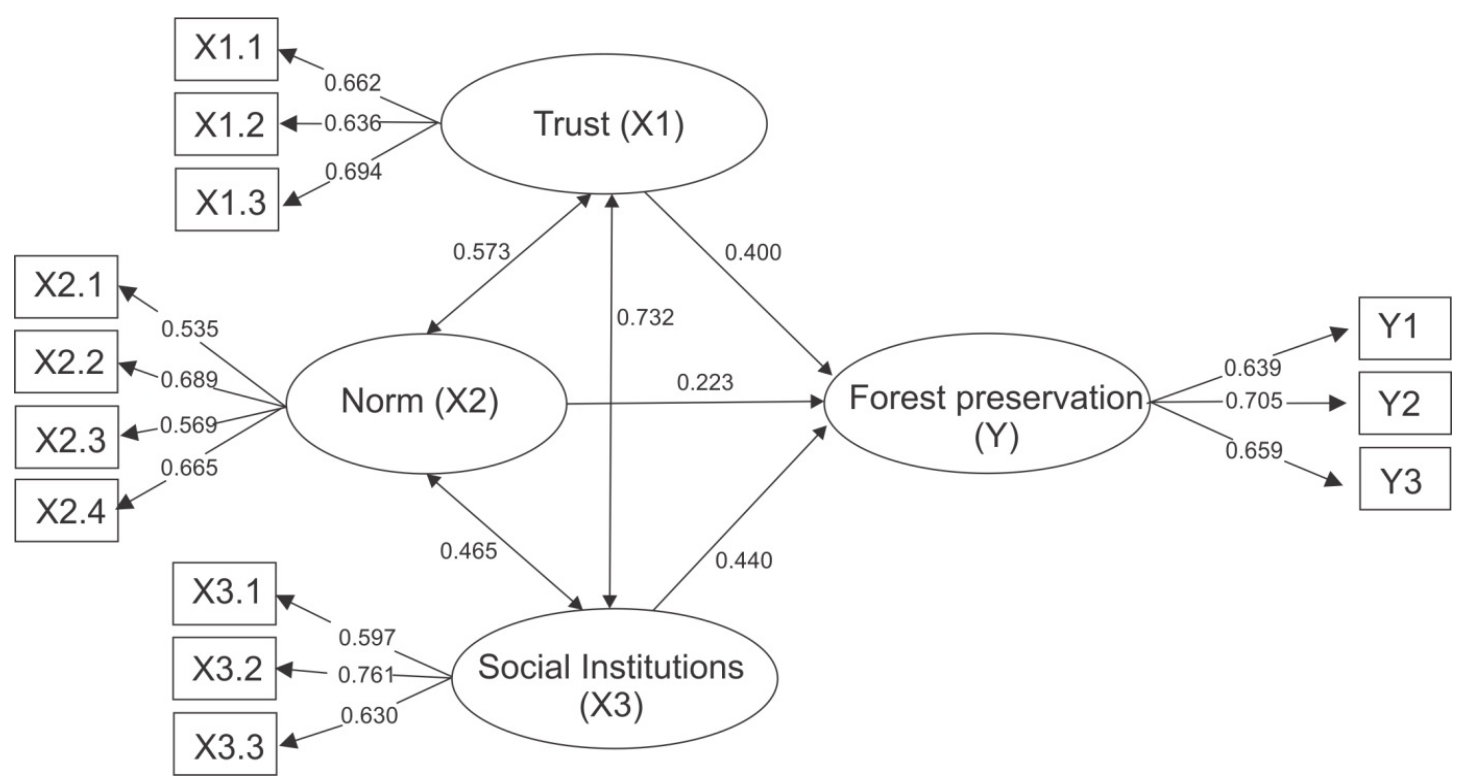

Source (Sumber): Data analysis, 2019

Figure1 Path of SEM analysis results Gambar 1 Hasil analisis jalur SEM.

Table 11 Research result on sustainability status index

Tabel 11 Hasil perhitungan indeks status keberlanjutan

\begin{tabular}{lccc}
\hline $\begin{array}{c}\text { Dimension } \\
(\text { Dimensi) }\end{array}$ & $\begin{array}{c}\text { Sustainability index } \\
\text { (Indeks keberlanjutan) }(\%)\end{array}$ & $\begin{array}{c}\text { Stress value } \\
(\text { Batas })\end{array}$ & $\mathrm{R}^{2}$ \\
\hline Ecology $($ Ekologi) & 54.68 & 0.15 & 0.97 \\
Economy (Ekonomi) & 36.46 & 0.17 & 0.91 \\
Social (Sosial) & 45.40 & 0.21 & 0.94 \\
\hline
\end{tabular}

Source (Sumber): Data analysis, 2019.

where stress value ranges between 0.15 0.21 and coefficient of determination value is 0.91-0.97 (Table 11). Based on Kavanagh $\&$ Pitcher (2004), the results of analysis are considered to be accurate and accountable if the stress value is less than 0.25 and the coefficient of determination (R2) is close to 1 (Appendix).

To see the error rate in Rap-Agroforestry analysis with MDS, a Monte Carlo analysis with $95 \%$ confidence level was performed. The result of Monte Carlo analysis shows that the Argosari village sustainability index value as an agroforestry area at $95 \%$ confidence level shows the result which is not much different from the result of MDS analysis. This means that errors in the analysis and data analysis process performed can be minimized (Table 12). MDS also makes data collection and processing easier.

\section{Sustainability on Dimensions}

The result of analysis using Rapagroforestry software shows that the ecology dimension studied is quite accurate and can be accounted for, where the stress value is 0.15 and the coefficient of determination is 0.97 . The results of observations in the field show the stability of land cover over 10 years. Meanwhile, when viewed from the analysis of Monte Carlo obtained sustainability index of ecological dimensions of $55.00 \%$. The conservation of ecological agroforestry system sectors 
Table 12 Differences of sustainability index values of Monte Carlo analysis with Rap-agroforestry analysis Tabel 12 Perbedaan nilai indeks keberlanjutan analisis Monte Carlo dengan analisis Rap-agroforestry

\begin{tabular}{lccc}
\hline \multirow{2}{*}{$\begin{array}{c}\text { Dimension of sustainability } \\
\text { (Dimensi keberlanjutan) }\end{array}$} & \multicolumn{2}{c}{$\begin{array}{c}\text { Value of sustainability index } \\
\text { (Nilai indeks keberlanjutan) }(\%)\end{array}$} & \multirow{2}{*}{$\begin{array}{c}\text { Difference } \\
\text { (Beda) }\end{array}$} \\
\cline { 2 - 3 } & MDS & Monte Carlo & 0.32 \\
Ecology (Ekologi) & 54.68 & 55.00 & 0.86 \\
Economy (Ekonomi) & 36.46 & 37.32 & 0.31 \\
Social (Sosial) & 45.40 & 45.71 & \\
\hline
\end{tabular}

Source (Sumber): Data analysis, 2019.

has had a considerable impact on ecological development in Malang regency. Sensitive attributes have an effect on the sustainability of the agroforestry system sustainability on ecological dimension, i.e protected water resources, minimized soil erosion and maintained soil quality, the establishment of land use that ensures biodiversity, and endangered species and plants are protected.

The result of MDS analysis using Rap-agroforestry software shows that the economic dimension studied is quite accurate and can be accounted for, where the stress value is 0.17 and the coefficient of determination is 0.91 as listed in Table 11 . A small stress value indicates the accuracy of this analysis. In addition, the description of the stability of land cover in the field also supports this value. In the analysis using Monte Carlo obtained sustainability index of social dimension of $37.32 \%$. The condition of the economic dimension is based on its status in the less sustainable category. This is possible because some attributes that are thought to be sensitive have an effect on the sustainability level of the system conservation of the agroforestry area on the economic dimension of economic importance derived from forest resources, the profit as a permanent livelihood derived from agroforestry.

The result of the analysis shows that the social dimension being studied is quite accurate and can be accounted for, where the stress value is 0.21 and the coefficient of determination is 0.94 . When compared with the value of sustainability index with Monte Carlo obtained a difference of $0.31 \%$, where the index value is $45.71 \%$. The difference is relatively small so it can be stated that the results of the analysis are valid and accurate. Argosari village's sustainability status as a conservation of the agroforestry system in terms of social dimension is in a less sustainable condition. The lack of sustainability of the social dimension is possible because this area has not been fully addressed by local and provincial governments. Attributes that may affect the value of the sustainability index of the social dimension include community education, active participation in members, participatory decision-making, conflict resolution mechanisms and community access to guaranteed forest resources.

Most of community respond to the indicators the researchers offer as 'neutral'. This means there is a community that has no communal purpose in environmental sustainability (de Foresta et al., 2000; Deb et al., 2009). On the other hand, they have understood that environmental damage is a causal link, which in turn will have an impact on the economy, then their social life (Tamborra, 2002; Almeida, Cruz, Barata, \& Garcia-Sanchez, 2017). This is illustrated by only a small percentage of community who respond with disagreement. It is neutral to positive for the sustainability of Argosari village agroforest on the ecological side.

In depth, the results of the MDS-Rapagroforestry analysis show some of the 
most influential factors on ecological sustainability (Figure 2). The condition of the hidrology system in Argosari village is felt very well by the community, so it ranks first from the opinions of the respondents. This result is shown as the most sensitive attribute to the sustainability level of Argosari village agroforest.

Water is the basic necessity of life and agricultural activities in the world, including agroforests. This system allows for water savings through silvicultural methods, both modern, and traditional (Roose \& Ndayizigiye, 1997; Zomer et al., 2007). Perhutani plant is a type of hard wood with a dense shade, combined with certain types of plants that can live under the shade. In Argosari village agroforest system, po trees, mahogany, suren, and eucalyptus become the main plant owned by PT. Perhutani. People can rent the land for Rp200,000300,000 every year. The parts in between the production plants are planted with other unobtrusive small plants, such as cabbage, chilli, spring onions, potatoes on land with unprofitable production trees. But for other plants with thick canopies, coffee is the only type of plant used.

The agroforest system has been proven to make land sustainable. Indonesia's traditional silviculture system allows soil resistance to erosion, in the absence of open cracks for falling rainfall (de Foresta et al., 2000). In addition, a more dense root system also traps the soil in order to avoid landslides (Gyssels, Poesen, Bochet, \& Li, 2005; Underhill, 2013; Reubens, Poesen, Danjon, Geudens, \& Muys, 2007). Areas with agroforest systems are also capable of providing protection and resources to protected animals. Recorded agroforest system capable of providing resources to elephant sumatra (Elephas maximus sumatranus) and sumatran tiger (Panthera tigris sondaica) (de Foresta et al., 2000; Nyhus \& Tilson, 2004; Kusters et al., 2008).

From the economic dimension, sensitive attributes are economic interests derived from forest resources. Argosari village community uses forest as fuel wood. In other than expensive energy, firewood is the best choice for community with lower

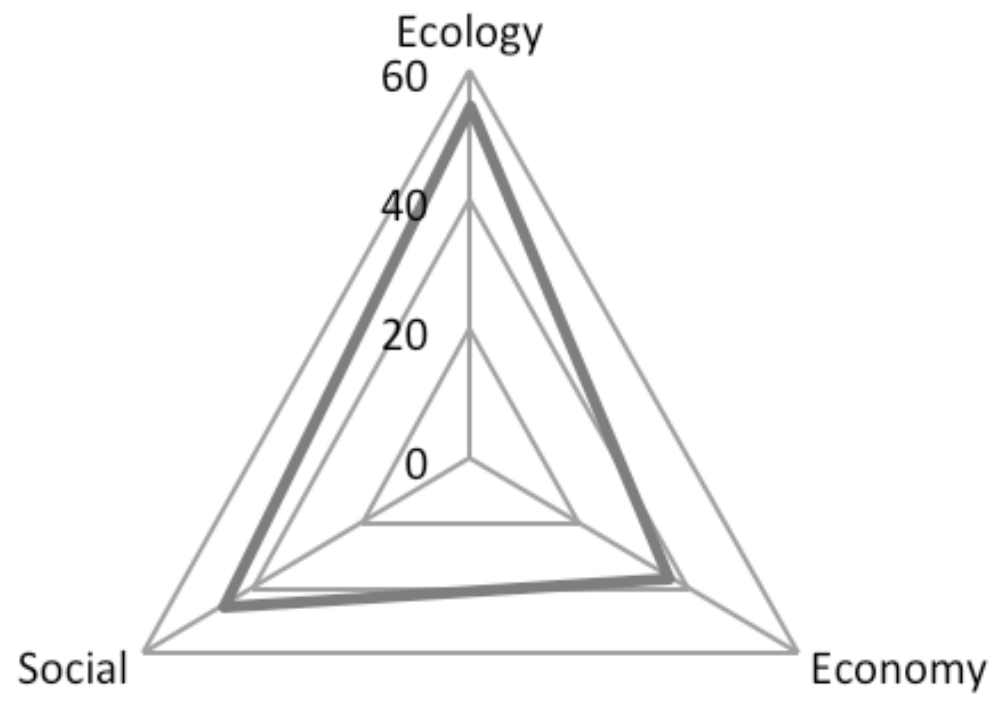

Source (Sumber): Data analysis, 2019

Figure 2 The radar graph of MDS. Ecology becomes the most sustainable attribute in Argosari's agroforest system, compared to the other two dimensions

Gambar 2 Grafik radar MDS. Ekologi menjadi atribut paling berkelanjutan dalam sistem agroforestri di Argosari, dibandingkan dengan dua dimensi lainnya. 
middle-class economies. Although most communities have other sources of energy, such as gas stoves, firewood is still sought for combustion systems for processed species that require a long time (FAO, 2010; May-Tobin, 2011; Subarudi, 2014).

Argosari communities also benefit the agroforest area as a source of animal feed, such as goats and cattle. The grass is dotted every day in rotation at the location, so the animal feed will not be exhausted and sustained. Some communities grow elephant grass (Pennisetum purpureum) and kalanjana (Brachiaria mutica) on the edge of the field. This grass has a double function, namely animal feed and steep edge of the soil. As animal feed, these two types of grass have fast growing properties. The farmer/landowner should cut as close to the root as possible, so that the next growth will spread and have many offspring. The more grass that grows, the root braid will be able to hold the soil to avoid landslides or erosion by rainwater.

In addition, Argosari community also use the agroforest area as a source of forest honey. Bee species such as Apis dorsata and A. florea were taken from the trees in agroforests. These bees often absorb nectar from coffee flowers, or flowers from trees in the forest. Forest honey is a valuable commodity for farmers. They can sell it for a higher price.

To maintain the sustainability of agroforests in Argosari village, (i) the unification of stakeholders from the community, businessmen and government in agroforest management, (ii) avoiding the price gap of forest commodities by establishing cooperatives, which will provide fair price incentives and product/ price information which is transparent, and (iii) formulates the pooling of stakeholder bodies. In order to strengthen social capital in agroforestry management, first, there needs to be innovation in the products. Second, increase partnerships with product consumers and investors. Third, form alliances from community groups. Fourth, the transformation of values towards people who care about the environment.

\section{CONCLUSION AND SUGGESTION}

\section{A. Conclusion}

The results of the MDS-Rap-agroforestry analysis show some of the most influential dimension on ecological sustainability, i.e. ecology. Ecology is a main dimension affecting the sustainability of agroforest systems in Argosari village. The condition of the water system in Argosari village is felt very well by the community, so it ranks first from the opinions of the respondents. This result is shown as the most sensitive attribute to the sustainability level of Argosari village agroforest. Public awareness in managing land in line with forest conservation is a major factor supporting sustainability.

\section{B. Suggestion}

Ecology is the most influential dimension on the sustainability of the agroforest system in Argosari village, so it needs to be maintained. Communities, who are members of various social groups, need to increase profits from social capital, because of its potential to support sustainability. To increase social capital benefits for agroforest sustainability in Argosari village, government and/or stakeholder interventions are needed to support the stability of forest product prices, such as honey, livestock, pine resin, and eucalyptus through cooperatives and home industries. Agriculture and forestry counselor can utilize the existence of farmer groups to conduct counseling in order to improve the existing agroforestry system for the environment and community income.

\section{ACKNOWLEDGEMENT}

The authors thank to the government of Argosari village, Jabung sub-district, and 
Malang regency for the permission of the research. Thank must also go to the Argosari village community for their assistance and research-related information. We also thank to Mr. Slamet, head of Argosari Village Farmer Group, for his assistance and valuable information.

\section{REFERENCES}

Almeida, TAdN, Cruz, L., Barata, E., \& GarciaSanchez, I-M. (2017). Economic growth and environmental impacts: An analysis based on a composite index of enviromental damage. Ecological Indicators, 76, 119-130.

Arikunto, S. (2006). Prosedur penelitian suatu pendekatan praktek. Jakarta: PT. Rineka Cipta.

Augusty, F. (2006). Metode penelitian manajemen: pedoman penelitian untuk penulisan skripsi, tesis dan disertasi ilmu manajemen. Semarang: Badan Penerbit Universitas Diponegoro.

de Foresta, H., Kusworo, A., Michon, G. \& Djatmiko, W.A. (2000). Ketika kebun berupa hutan: Agroforest khas Indonesia, sebuah sumbangan masyarakat. Jakarta: SMT Grafika Desa Putra.

Deb, S.A., Arunachalam, \& Das, A.K. (2009). Indigenous knowledge of Nyishi tribes on traditional agroforestry systems. Indian Journal of Traditional Knowledge, 8(1), 4146.

Food and Agriculture Organization (FAO). (2010). Woodfuels and climate change mitigation: case studies from Brazil, India, and Mexico. Rome: UN.

Fauzi, A. \& Anna, S. (2005). Permodelan sumber daya perikanan dan kelautan. Jakarta: PT. Gramedia Pustaka Utama.

Fauzi, A. \& Anna, S. (2002). Evaluasi status keberlanjutan pembangunan perikanan: aplikasi pendekatan Rapfish. Indonesian Journal of Coastal and Marine Resources, 4(3), 43-55.

Fauzi, A. (2004). Ekonomi sumber daya alam dan lingkungan; teori dan aplikasi. Jakarta: PT Gramedia Pustaka Utama

Field, J. (2005). Social capital and lifelong learning. Retrieved 22 June 2011 from http://www. infed.org/lifelonglearning/social_capital_ and lifelong_learning. htm.

Gyssels, G., Poesen, J., Bochet, E. \& Li, Y. (2015). Impact of plant roots on the resistence of soils to erosion by water: a review. Progress in Physical Geography, 29(2), 189-217.

Kavanagh, P. \& Pitcher, T.J. (2004). Implementing Microsoft Excel Software for rapfish: a technique for the rapid appraisal of fisheries status, Tech. Rept. 12.2. Vancouver: Fisheries Centre Research Reports.

Kusters, K., Ruiz Pérez, M, Manalu, P, Nawir, A., de Foresta, H., Belcher, B., \& Wollenberg, E. (2008). Will agroforests vanis? The case of damar agroforests in Indonesia. Human Ecology, 36, 357-370.

Lim, C.H., Choi, Y., Kim, M., Jeon, S.W., and Lee, W.K. (2017). Impact of deforestation on agroenvironmental variables in cropland, North Korea. Sustainability, 9(1354), 1-19.

Mayrowani, H. \& Ashari. (2011). Pengembangan agroforestry untuk mendukung ketahanan pangan dan pemberdayaan petani sekitar hutan. Brief no. 06 Policy Analysis Unit.

May-tobin, C. (2011). The root of the problem: what's driving tropical deforestation today? Wood for Fuel (Chapter 8). Union of Concerned Scientists. Retrieved 13 June 2018 from http:// ucsusa/org/whatsdrivingdeforestation.

Ministry of Forestry. (2006). Promosi hasil pengelolaan hutan berbasis masyarakat (CBFM). Retrieved 20 September 2013 from www.dephut.go.id/index.php?q=id/ node/2629.

Nababan, A. (2003). Pengelolaan sumberdaya alam berbasis masyarakat. Retrieved July 2014 from http://www.ulayat.or.id/artikel/ pengelolaan_sumberdaya_alam_berbasis masyarakat_adat/.

Nyhus, P. \& Tilson, R. (2004). Agroforestry, elephants, and tigers: balancing conservation theory and practice in human-dominated landscapes of Southeast Asia. Agriculture Ecosystems and Environment, 104, 87-97.

Parotta, J.A., Fui, L.H., Jinlong, L., Ramakrishnan, P.S., \& Yeo-Chang. (2009). Traditional forestrelated knowledge and sustainable forest management in Asia. Forest Ecology and Management, 257(10), 1987-1988.

Preece, J. (2006). Participatory Rural Appraisal: lessons for countries in the North? International Journal of Action Research, 2(2), 1-24.

Putnam, R.D.B. (2001). Bowling alone: the collapse and revival of American community. Journal of Catholic Education, 6, 2.

Reubens, B., Poesen, J., Danjon, F., Geudens, G., \& Muys, B. (2007). The role of fine and coarse roots in shallow slope stability and soil erosion control with a focus on root system 
architecture: a review. Trees, 21(4), 385-402.

Roose, E. \& Ndayizigiye, F. (1997). Agroforestry, water and soil fertility management to fight erosion in tropical mountains of Rwanda. Soil Technology, 11(1), 109-119.

Subarudi. (2014). Analisis kelayakan sosial, finansial, dan pasar produk hutan tanaman rakyat: studi kasus di Kabupaten Dompu, Nusa Tenggara Barat. Jurnal Penelitian Sosial dan Ekonomi Kehutanan, 11, 323-327.

Suhartini. (2009). Kajian kearifan local masyarakat dalam pengelolaan sumberdaya alam dan lingkungan. Prosiding Seminar Nasional Penelitian, Pendidikan, dan Penerapan MIPA, Yogyakarta, May 16, 2009. Yogyakarta: Jurusan Pendidikan Biologi, FMIPA, Universitas Negeri Yogyakarta.

Tamborra, M. (2002). Socio economy tools for sustainability impact assessment. Luxemburg: Office of European Communities.

Underhill, B.L. (2013). The influence of vegetation and roof density on erosion for three streams in Minnesota (Thesis). Faculty of sciences, University of Minnesota.
Zomer, R.J., Bossion, D.A, Trabucco, A., Yuanjie, L., Gupta, D.C., \& Singh, V.P. (2007). Trees and water: Smallholder agroforestry on irrigated lands in Northern India. Colombo: International Water Management Institute. 


\section{APPENDIX}

1 Main data variable used (Variabel data utama yang digunakan)

\begin{tabular}{|c|c|c|c|c|}
\hline Variable (Variable) & Indicator (Indikator) & Item & Validity (Validitas) & $\begin{array}{c}\text { Reliability } \\
\text { (Reliabilitas) }\end{array}$ \\
\hline \multirow[t]{9}{*}{ Trust (Kepercayaan) (X1) } & \multirow[t]{3}{*}{$\mathrm{X} 1.1$} & $\mathrm{X} 1.1 .1$ & 0.494 & \multirow{9}{*}{0.661} \\
\hline & & $\mathrm{X} 1.1 .2$ & 0.492 & \\
\hline & & $\mathrm{X} 1.1 .3$ & 0.486 & \\
\hline & \multirow[t]{3}{*}{$\mathrm{X} 1.2$} & $\mathrm{X} 1.2 .1$ & 0.579 & \\
\hline & & $\mathrm{X} 1.2 .2$ & 0.565 & \\
\hline & & $\mathrm{X} 1.2 .3$ & 0.447 & \\
\hline & \multirow[t]{3}{*}{$\mathrm{X} 1.3$} & $\mathrm{X} 1.3 .1$ & 0.532 & \\
\hline & & $\mathrm{X} 1.3 .2$ & 0.532 & \\
\hline & & $\mathrm{X} 1.3 .3$ & 0.549 & \\
\hline \multirow[t]{12}{*}{ Ecology (Ekologi) (X2) } & \multirow[t]{3}{*}{$\mathrm{X} 2.1$} & $\mathrm{X} 2.1 .1$ & 0.458 & \multirow[t]{12}{*}{0.653} \\
\hline & & $\mathrm{X} 2.1 .2$ & 0.501 & \\
\hline & & $\mathrm{X} 2.1 .3$ & 0.381 & \\
\hline & \multirow[t]{3}{*}{$\mathrm{X} 2.2$} & $\mathrm{X} 2.2 .1$ & 0.488 & \\
\hline & & $\mathrm{X} 2.2 .2$ & 0.398 & \\
\hline & & $\mathrm{X} 2.2 .3$ & 0.428 & \\
\hline & \multirow[t]{3}{*}{$\mathrm{X} 2.3$} & $\mathrm{X} 2.3 .1$ & 0.373 & \\
\hline & & $\mathrm{X} 2.3 .2$ & 0.532 & \\
\hline & & $\mathrm{X} 2.3 .3$ & 0.609 & \\
\hline & \multirow[t]{3}{*}{$\mathrm{X} 2.4$} & $\mathrm{X} 2.4 .1$ & 0.381 & \\
\hline & & $\mathrm{X} 2.4 .2$ & 0.511 & \\
\hline & & $\mathrm{X} 2.4 .3$ & 0.407 & \\
\hline \multirow[t]{9}{*}{ Social (Sosial) (X3) } & \multirow[t]{3}{*}{$\mathrm{X} 3.1$} & X3.1.1 & 0.440 & \multirow[t]{9}{*}{0.656} \\
\hline & & X3.1.2 & 0.555 & \\
\hline & & X3.1.3 & 0.531 & \\
\hline & \multirow[t]{3}{*}{ X3.2 } & X3.2.1 & 0.590 & \\
\hline & & X3.2.2 & 0.554 & \\
\hline & & X3.2.3 & 0.534 & \\
\hline & \multirow[t]{3}{*}{$\mathrm{X} 3.3$} & $\mathrm{X} 3.3 .1$ & 0.479 & \\
\hline & & $\mathrm{X} 3.3 .2$ & 0.456 & \\
\hline & & X3.3.3 & 0.507 & \\
\hline \multirow{9}{*}{$\begin{array}{c}\text { Forest preservation } \\
(\text { Pelestarian hutan })(\mathrm{Y})\end{array}$} & \multirow[t]{3}{*}{ Y1 } & Y1.1 & 0.451 & \multirow[t]{9}{*}{0.656} \\
\hline & & $\mathrm{Y} 1.2$ & 0.500 & \\
\hline & & Y 1.3 & 0.553 & \\
\hline & \multirow[t]{3}{*}{$\mathrm{Y} 2$} & $\mathrm{Y} 2.1$ & 0.488 & \\
\hline & & Y 2.2 & 0.518 & \\
\hline & & Y 2.3 & 0.570 & \\
\hline & \multirow[t]{3}{*}{$\mathrm{Y} 3$} & Y3.1 & 0.504 & \\
\hline & & Y3.2 & 0.586 & \\
\hline & & Y3.3 & 0.479 & \\
\hline
\end{tabular}


2 Test validity and instrument reliability results (Hasil uji validitas dan reliabilitas instrument)

\begin{tabular}{|c|c|c|c|c|c|}
\hline No & Aims (Tujuan) & $\begin{array}{l}\text { Variables } \\
\text { (Variable) }\end{array}$ & Indicator (Indikator) & $\begin{array}{l}\text { Data type } \\
\text { (Tipe } \\
\text { data) }\end{array}$ & $\begin{array}{l}\text { Data source } \\
\text { (Sumber } \\
\text { data })\end{array}$ \\
\hline \multirow[t]{4}{*}{1.} & \multirow[t]{4}{*}{$\begin{array}{l}\text { Analyzing the factors } \\
\text { that strengthen the } \\
\text { role of social capital } \\
\text { in agroforestry system } \\
\text { in Argosari village, } \\
\text { Jabung district, } \\
\text { Malang regency }\end{array}$} & Trust & $\begin{array}{l}\text { - a prohibition to cut down } \\
\text { productive trees } \\
\text { - maintenance of environmental } \\
\text { balance } \\
\text { - the success of planting is } \\
\text { related to environmental } \\
\text { phenomena such as plants, } \\
\text { animals, or moon }\end{array}$ & Primary & Respondent \\
\hline & & Norm & $\begin{array}{l}\text { - ban on cutting trees } \\
\text { - planting crops around the forest } \\
\text { - replanting for sustainability } \\
\text { - tradition event relating to } \\
\text { nature }\end{array}$ & Primary & Respondent \\
\hline & & Social & $\begin{array}{l}\text { - institutional goals } \\
\text { - institutional structure } \\
\text { - effectiveness of the institution }\end{array}$ & Primary & Respondent \\
\hline & & Agroforestry & $\begin{array}{l}\text { - guaranteed sustainability of } \\
\text { production } \\
\text { - ensuring the sustainability } \\
\text { of ecological/environmental } \\
\text { functions } \\
\text { - ensuring the sustainability of } \\
\text { social functions }\end{array}$ & Primary & Respondent \\
\hline \multirow[t]{3}{*}{2.} & \multirow{3}{*}{$\begin{array}{l}\text { Analyzing the } \\
\text { sustainability of } \\
\text { the conservation of } \\
\text { agroforestry system } \\
\text { from the ecological, } \\
\text { social, and economic } \\
\text { aspects of Argosari } \\
\text { village, Jabung } \\
\text { district, Malang } \\
\text { regency }\end{array}$} & $\begin{array}{l}\text { Ecology } \\
\text { sustainability }\end{array}$ & $\begin{array}{l}\text { - water resources are protected } \\
\text { - minimize soil erosion and soil } \\
\text { quality maintained } \\
\text { - establishment of land use that } \\
\text { ensures diversity } \\
\text { - endangered species and plants } \\
\text { are protected }\end{array}$ & Primary & Respondent \\
\hline & & $\begin{array}{l}\text { Social } \\
\text { sustainability }\end{array}$ & $\begin{array}{l}\text { - Community education } \\
\text { - Active participation in groups } \\
\text { - Participatory decision making } \\
\text { - Conflict resolution mechanisms } \\
\text { - Community access to forest } \\
\text { resources is assured }\end{array}$ & Primary & Respondent \\
\hline & & $\begin{array}{l}\text { Economy } \\
\text { sustainability }\end{array}$ & $\begin{array}{l}\text { - Economic interests derived } \\
\text { from forest resources } \\
\text { - Profit as a permanent livelihood } \\
\text { derived from agroforestry }\end{array}$ & Primary & Respondent \\
\hline
\end{tabular}

